\title{
Lapurdum
}

Euskal ikerketen aldizkaria | Revue d'études basques |

Revista de estudios vascos | Basque studies review

$8 \mid 2003$

Numéro VIII

\section{La poesía amatoria en Bernard Etxepare y Amaud Oihenart}

Iñaki Aldekoa Beitia

\section{OpenEdition}

\section{Journals}

Edición electrónica

URL: http://journals.openedition.org/lapurdum/903

DOI: 10.4000/lapurdum.903

ISSN: 1965-0655

Editor

IKER

Edición impresa

Fecha de publicación: 1 noviembre 2003

Paginación: 7-17

ISBN: 9782867813436

ISSN: $1273-3830$

Referencia electrónica

Iñaki Aldekoa Beitia, «La poesía amatoria en Bernard Etxepare y Amaud Oihenart », Lapurdum [En línea], 8 | 2003, Publicado el 01 junio 2009, consultado el 10 diciembre 2020. URL : http:// journals.openedition.org/lapurdum/903; DOI : https://doi.org/10.4000/lapurdum.903 


\section{Iñaki Aldekoa Beitia}

\section{La poesía amatoria en Bernard Etxepare y Arnaud Oihenart}

Una de las muchas canciones en honor de la Virgen María reunidas por el rey de Castilla Alfonso X el Sabio !, en el siglo XIII, narra la leyenda de una guapa monja que, siendo tesorera de su convento y profundamente devota de la Virgen, se enamora de un caballero y se fuga con él. No lo hace, sin embargo, antes de dirigirse al altar y encomendar a la Virgen la custodia de las llaves. Mientras la monja tiene varios hijos con su amante, la Virgen toma su figura y le sustituye en los deberes conventuales. Finalmente la monja se arrepiente, abandona a su amante y vuelve temerosa a su convento, donde encuentra las llaves y el hábito en el mismo lugar donde los había depositado. Una vez allí, cuenta a sus hermanas lo sucedido y, sin escándalo alguno para nadie, la cantiga termina con un gozoso agradecimiento a la Virgen.

El desenfado y la ingenua superficialidad en la que vive la protagonista de esta canción revela con un colorido intenso el tono vital de una época que abarca las cantigas del rey Alfonso X, El Libro del Buen Amor del Arcipreste de Hita o las baladas de F. Villon. En este tono vital y espiritual se inserta la obra poética de B. Etxepare: es poeta de la vida y ninguna satisfacción, incluidos los apetitos carnales, le es ajena. Si penetramos en el sentimiento religioso y amoroso que resuena en sus poesías, nos sorprenderá el sentido práctico inherente a todos ellas. A los himnos más piadosos que dan fe del ardor religioso, con sus temores y éxtasis, les suceden los versos más licenciosos, realistas y profanos. Y no se dude de la prominencia de los primeros sobre los segundos o viceversa. Lo que para la mentalidad moderna parece una contradicción inconciliable no lo fue hasta bien entrado el Renacimiento. Las loas a la Virgen no sufren menoscabo al lado de la promesa de "yazer con fembra placentera".

Desde una profunda comprensión del Otoño de la Edad Media, J. Huizinga hace la siguiente reflexión: 
"Es algo casi incomprensible para nosotros la ingenuidad con que se injertaban en la vida diaria las prácticas religiosas en los días anteriores al Concilio de Trento (...). En todas estas profanaciones de la fe y en su descarada mezcla con la vida del pecado, habla más bien una ingenua famuliaridad con el culto divino que una irreligiosidad sistemática. Sólo una sociedad que está impregnada de religión y que considera la fe como algo natural conoce semejantes licencias..."

Ya Oihenarte ${ }^{2}$ había sucumbido a la severidad y al rigor racionalista de los nuevos tiempos, cuando, a tan sólo un siglo de distancia, fue incapaz de salvar los, aparentemente, inconciliables extremos, y ofrecer, desde el privilegio que le otorgaba la proximidad histórica, un testimonio más ajustado al sentido de la vida tardomedieval al que respondía la figura de Etxepare. No en vano había estallado entre tanto el cisma protestante (s. XVI) y se habían tomado las deliberaciones para combatirlo a partir del Concilio de Trento (1545-1563), coincidiendo con la publicación del libro de Etxepare. Las medidas que emanaron de Trento con el fin de combatir la Reforma cristalizaron en el espíritu de la" Contrarreforma". El gran salto se había producido: en cuestión de pocas décadas había quedado atrás, irreconocible, el mundo medieval, y Europa se adentraba en una época de severidad y rigor, de disciplina y racionalismo. Entre ambos poetas se interpuso la Reforma de Lutero y Calvino, por un lado, e Ignacio de Loyola y la Compañía de Jesús, por el otro. A las Reformas religiosas sucedió la época en que la ciencia y la razón -con Descartes y Galileo al frente- recibieron un impulso decisivo. La esperanza y la confianza en el futuro que el humanismo renacentista había alumbrado, resultó oscurecida por las guerras de religión.

Aun así, los versos latinos que cita Oihenart en su L'Art Poétique Basque (1665), estrofas que constituyen para el autor el repertorio litúrgico más al alcance, coinciden plenamente con algunos de los principales motivos e imágenes de la primera parte de la obra de Etxepare, la "Doctrina Christiana": "Cum pastores" (así como los pastores protegen las ovejas del lobo, así nos ha de proteger Dios del pecado) ;"Stabat Mater" (la imagen de La Madre Dolorosa ante su hijo crucifijado) ;"Dies irae" (el poeta combina imágenes del Apocalipsis con el motivo de la muerte como la gran niveladora entre el rico y el pobre, el sabio y el ignorante).

\footnotetext{
${ }^{2}$ En L'Art Poétique Basque (1665), afirma Oihenart que lass poestas amatorias de Etxepare son tremendamente irrespetuosas para un hombre de iglesia y, sobre todo, improcedentes, al tratarse de un pastor de almas.
} 
Como exigía la devoción mariana, la "Doctrina Christiana" de Etxepare se clausura con súplicas de gracia a la Virgen para el Día del Juicio ("per te, virgo, sim defensus/in die indicii") y para que nos libre del tormento del infierno o, lo que es lo mismo, de las brasas del fuego eterno.

En definitiva, la "Doctrina cristiana" es una suerte de compendio de los rudimentos de la fe cristiana.

Con" Amorosen Gaztiguya" (Desengaño de amantes), nos deslizamos hacia la temática amatoria. El poema - una especie de preámbulo a los poemas de amor profano (los poemas III a XII, siguiendo la numeración establecida por R. Lafon) - es una invitación bienintencionada a evitar los amores profanos (pecaminosos) y a encomendarse en cuerpo y alma a la Virgen María, única amante que por su pureza inmaculada merece el fervor de nuestros desvelos. Siempre será la Virgen María el refugio de los pecadores, siempre será su figura familiar y entrañable. Ésta se traduce en un compromiso satisfactorio entre los requerimientos de un amor sagrado y los requerimientos más atractivos y profanos de la vida cotidiana o, lo que es lo mismo, de una gozosa complicidad con la vida.

De ahí que en el poema "Emazteen fabore" (En defensa de las mujeres), al elogio más alto y virtuoso que eleva a aquéllas al mismo círculo que envuelve a la Virgen María -"Dios mismo ama a una mujer más que a todo el mundo/Enamorado de una bajó del cielo"-, alejándolas de la maledicencia de los hombres, le sucede bruscamente, y sin asomo de pudor, una invitación descarada a los placeres de la carne:

Munduyan ez da gauzarik hain eder ez plazentik,

Nola emaztia gizonaren petik buluzkorririk;

Beso biak zabaldurik dago errendaturik,

Gizon horrek dagiela hartzaz nahi duyenik.

Io badeza dardoaz ere gorputzaren erditik, Ainguriak bano oboro ez larrake gaizkirik; Bana dardoa ematurik, zauri ere sendoturik, Bere graziaz ezartein'tu elgarreki baketurik. ${ }^{3}$

\footnotetext{
${ }^{3}$ A pesar de coincidir muchos de los estudiosos de la obra de Etxepare en señalar que los versos del poeta contienen quince sílabas, el consenso dista de ser unánime. Ver al respecto Jon Juaristi” De métrica vascorrománica", Donostia, ASJU, XXIV-2, 1990.

No es éste, sin embargo, el único interrogante que sigue abierto sobre la obra del poeta bajo-navarro. Efectivamente, no es de menor relevancia el que se refiere a la tradición lírica en la que se formó Etxepare. Por ahora no tenemos constancia suficiente de una tradición lírica en euskera anterior a Etxepare.
} 
(No hay en el mundo cosa tan hermosa y placentera/como la mujer desnuda debajo del hombre./Con los dos brazos abiertos, está rendida/para que el hombre haga lo que quiera de ella./Aunque la hiera con su dardo por medio del cuerpo/no dirá más mal que si fuese un ângel,/sino que, ablandado el dardo y sanada la herida,/con su gracia reconcilia a ambos.)

El poema entero no es sino un ejemplo entre tantos de lo que Rafael Lapesa definía como "la aplicación de lo sagrado a lo profano, tan irreverente según la sensibilidad nuestra y tan reiterada en el mundo medieval". Las razones que el poeta despliega en poemas como "En defensa de las mujeres" o en "Coplas de casados" son de una elementalidad ramplona y responden al brutal realismo del pueblo llano: el hombre planta su semilla (en la mujer), sobre campo arado y abonado.

"Bertzeren har dazanak beretako amore

(...)

Alhor hortan hel badakit ereitera hazia,

Eta ene bada ere lastoa eta bihia,

Ez bat ori ahal duket, ez etare bertzia;..."

("Quien se enamore de la que es de otro/(...)/Si me sucede sembrar en ese campo,/y por más que sean la paja y el grano míos, no podré disponer de una ni del otro...")

Ni el tono vital y espiritual del poeta Etxepare ni el público receptor a quien iban dirigidas las poesías, tenían mucho en común con aquella nueva sentimentalidad que a partir del siglo XII se difundió por toda Europa. Me refiero - claro está- al amor cortés, al nuevo código amatorio que vino a domesticar y a refrenar los impulsos más primarios de los caballeros, transmutando los valores guerreros en modelo de refinamiento e idealismo, es decir, en cortesía.

De ningún modo resultará válido para nuestro poeta un ritual que resuelve apaciguar el apetito carnal apelando a la cortesía. Por el contrario, la dama cuya respuesta no es otra que "kortesiaz hon deritzut nik zuri hain segurki" (Yo te amo, sí, cortesmente) será inmediatamente despreciada en "Amore gogorraren despita" (Desprecio de la amada cruel). El título del poema y lo que acontece en él no son del todo ajenos al motivo -también medieval- de la "Belle Dame sans merci" (La Bella Dama sin piedad) : la cor- 
tesía que invoca la Dama le parecerá una patraña, un subterfugio para escapar a sus requerimientos de satisfacción carnal.

Tampoco será precisamente "cortés" un temperamento que no se amilana ante el rechazo de la dama y, contraviniendo las reglas que la convención literaria exigía, la doblega y reduce en contra de su voluntad, como ocurre en el poema.

En” Amorosen Disputa “(Disputa de Amantes):

"Haraitzinakorik duzu errana,

utzi dazan orrek eskuyan duyena

nahi duyenian eztukeyela

¡Hitzak aribira, dugun egina!"

("De antiguo se dijo/que quien deja lo que en la mano tiene/no lo volverá a tener cuando lo quiera./Fuera las palabras, vayamos al hecho!")

Para finalizar, los dos últimos poemas, Contrapas (XIV) y Sautrela $(\mathrm{XV})$, escritos para que fueran cantados por el pueblo acompañando a la danza, vienen a exaltar el euskera sobre las demás lenguas del mundo, aprovechando la ocasión de la impresión por primera vez de un libro en lengua vasca.

Con gran entusiasmo saluda Etxepare la" Era Gutenberg", cuya novedad hace que el poeta mire con júbilo y optimismo el futuro del euskera.

Según Oihenart, se realizaron dos ediciones del libro de Etxepare y, a tenor del eco que obtuvo el poeta en boca de los hombres de letras que le sucedieron, no parece que el libro tuviera entre sus paisanos la difusión que le auguraba en sus versos finales.

\section{La poesía de Arnaut Oihenart}

No son muchas las metáforas que han gozado de la fortuna de aquélla que hace referencia a la clásica comparación entre ojos y estrellas. El primer ejemplo de esta comparación modélica procede de la Antología griega: "Desearía ser la noche para mirar tu sueño con mil ojos". Ese mirar del amante que aquí, evidentemente, percibimos cargado de ternura, será motivo de gozo y dolor, bienestar y sufrimiento, esperanza y temor, deseo y satisfacción en la tradición lírica amorosa de Occidente. 
La gran tradición amatoria de la lírica occidental arranca con la poesía provenzal del siglo XII y continúa ininterrumpidamente hasta los poetas del dolce stil nuovo y el Roman de la Rose en el siglo XIII, así como Petrarca en el siglo XIV y, bajo la larga estela de este último, hasta Oihenarte en el siglo XVII.

Desde el firmamento ("izartegia") de su amada, es decir, desde esas dos estrellas ("izar bi") que custodian su belleza, caen los rayos y las flechas que golpean y asaetean el corazón del amante. Es así como Amor hiere profundamente el corazón del galán enamorado y se aposenta en él. En adelante, éste no será dueño de sí mismo y su vida se trunca en una prisión : un cautiverio que será más o menos desdichado en función de la mirada cálida o fría (ardiente/helada) con que le obsequie la amada. De ahí que una de las antítesis mejor asentadas en la lírica de Petrarca, Ronsard u Oihenart, y por derivación en toda Ia lírica posterior hasta nuestros días, sea la que funde en un mismo abrazo el fuego y el hielo, el verano y el invierno: "y ardo, y soy un hielo" (Petrarca); "el fuego con que me hiela/el hielo con que me abrasa" (Lope de Vega); "Elhurrak alabadere/naduka ni, hots badere, errerik bihotzean" (Oihenarte) (La nieve, sin embargo, a pesar del frío, mantiene el fuego en mi corazón). El amante queda a merced de una mujer que sobresale por su belleza y virtud: blanca, rubia y esbelta, además de gentil y discreta. El pelo será, preferentemente, rubio como el oro (hasta el siglo XVIII será infrecuente el pelo moreno como sinónimo de belleza). Según sea la expresión de sus ojos más o menos esquiva, la mirada fulgurante de la amada ciega y hiela el corazón del amante hasta el punto de sentirse morir: "ciegan los rayos de un hermoso semblante" (Ronsard). Aun así, Petrarca ensalza dicho estado anímico ("la dulzura de este tormento... deleitoso pesar"), que para Oihenart hace que "el bosque se vista de flores, así como de hojas, por cuatro veces. El verano se vuelve invierno, y el invierno verano, otras tantas veces".

El amor es una convención literaria ${ }^{4}$, es decir, nos encontramos ante un repertorio de sentimentos imaginariamente tipificados. Había quedado atrás el mundo del vasallaje feudal, pero la ficción poética que surgió con el

\footnotetext{
4 En este sentido, resulta intranscendente preguntarse sobre la realidad de los distintos nombres tras los que se escuda el Amor de Oihenart. Por supuesto que son fingidos. La convención poética a la que se acoge Oihenart sacrificaba la singularidad de los sentimientos a favor de unos sentimientos genéricos. En pleno siglo XX, A. Machado se hace eco de una fórmula similar:"Todo amor es fantasía, Jél inventa el año, el día.../No importa nada/para el amor que la amada/no haya existido jamás". Aun tratándose de sugestiones fingidas, no son por ello menos verdaderas.
} 
amor cortês continuó irradiando buena parte de la lírica posterior en Occidente: la mujer seguirá ostentando la única potestad y libertad para dar o negar su amor al galán que la requiera, el cuál no gozará de otra opción que la súplica. Así lo confirman los versos de Oihenart: "Maitarien jaun erregeak/higu ditu bortxalegeak/eta haren erresuman libertatea da gobernari" ("Soberanos del amor odian las razones violentas. En su reino la libertad es soberana"). En caso contrario sería lícito el adulterio (O64). No le resta, pues, al amante otra alternativa que la súplica y que ésta despierte la piedad de la amada y reconozca los grandes méritos de aquél: el gran sufrimiento que le embarga, así como su larga espera. En definitiva: no habrá otro "siervo" tan leal y que le quiera tanto. A menudo estas súplicas adoptan un tono conminatorio hacia la mujer y su buen nombre.

No es la de Oihenart una poesía que destaque ni por su originalidad ni por la penetración en los sentimientos humanos; responde, por el contrario, a pautas imaginarias absolutamente previsibles. Como se ha dicho ya, la poesía de Oihenart responde a un repertorio de afectos y sentimientos tipificados que cristalizaron en el modelo petrarquista del siglo XVI. Seguramente el único poema amoroso que revela sentirse algo incómodo dentro de dicha convención poética sea el poema titulado "Eskontidearen hil-kexua", en el que Oihenart arremete contra las musas ("las nueve hermanas"), que de nada han servido para evitar la muerte de su mujer. Como lo hiciera en un arranque contra el petrarquismo el poeta Du Bellay, integrante de la Pléiade, - "he olvidado petrarquizar/quiero conversar, francamente de amor"-, el poeta de Zuberoa quiere desprenderse del artefacto literario entendido como puro juego formal para enfretar el sufrimiento humano y real de la muerte de Joana, su mujer.

Efectivamente, el Canzoniere de Petrarca se convirtió a partir del siglo XVI en la referencia ineludible - el auténtico diapasón- de la lírica europea. Importado de Italia, el soneto ("hamalaurkuna") se consagró como el fruto más sazonado de un proceso de refinamiento poético y formal. Poetas como el Marqués de Santillana o Juan de Mena aspiraban ya en la poesía española del siglo XV a una elevación espiritual y formal imitando el "itálico modo". Una aspiración que, como en el caso de la poesía de Oihenart, no estaba exenta de lo que semejante tendencia comportaba de refinamiento social. De ahí que el amante de uno de los poemas del autor $(\mathrm{O} .15)$ solicite vívamente de su señora un trato más distinguido que el que le dispensaba a gentes de oficios vulgares. Con Boscán y Garcilaso de la Vega en la poesía española o Clément Marot y Pierre Ronsard en la francesa la incorporación de la tradición petrarquizante es ya un hecho cultural incuestionable. Estamos en el 
s. XVI, el siglo del Renacimiento literario europeo y de la expansión del Humanismo cristiano y platonizante (Ficino acuñó el término de amor platónico); pero también son los años de la Contrarreforma y de los "Index librorum prohibitorum" (1559). Había quedado atrás el sistema de valores medieval en su vertiente más popular y se imponía un ideal de refinamiento clásico que aspiraba a imitar "el sistema de formas" de los creadores antiguos. La influencia petrarquista y la expansión de la imprenta son algunas claves de este cambio que se vivió en todos los ámbitos de la cultura que venía a apuntalar el triunfo del Renacimiento.

Todo esto coincide con los años de publicación de las "Ars Poeticas", como códigos formales para la,poesía: en 1545 se traduce al francés el Ars Poetica de Horacio, al que seguirán no pocos tratados de poética. Oihenart haría lo propio un siglo más tarde. Aunque no se llegó a publicar hasta 1967 , Oihenart fue autor de L'art poétique hasque (1667). A aquellos años pertenece la influyente Défense et illustration de la langue française (1549) de Joachim Bellay, así como las "Prosas de la vulgare lingua" (1525) del veneciano Pietro Bembo y el Diálogo de la lengua (1535) del español Juan de Valdés que, en un intento similar, sentaron las bases que procuraron la igualación entre el latín y las lenguas romances. No olvidemos que al igual que Oihenart, Du Bellay y todos sus coetáneos escribían también en latín. De ahí que fuera necesario el cultivo del francés, el italiano, el español o el euskera como lengua poética, aun si para ello no se tuvieran en cuenta más que aquellos autores que habían bebido de las fuentes clásicas (italianizante y poesía latina, fundamentalmente): "Abandonad todas esas viejas poesías francesas como los rondós, baladas, virelais, canciones y otras viejas reliquias...".

No es otro el caso de Oihenart: escribió en latín un libro de historia de los vascos, Notitia utriusque Vasconiae (1638); escribió L'art poétique basque (1665) en francés y la recopilación de proverbios y poesías, Les proverbes Basques recuellis par le Sr. d'Oihenart, plus les poésies basques du même auteur (Atsotitzak edo refrauak eta $\mathrm{O}$. ten gastaroa neurthitzetan) (1657), que lo hizo en euskera. Los poetas de "La Pléiade" despreciaron a los poetas que no habían forjado sus metros en la escuela clásica. También Oihenarte despachó como "vulgares versificadores" a los poetas que habían escrito con anterioridad a él. Si el poeta Bernard Etxepare se enorgullecía de haber sido el primero en publicar un libro en lengua vasca, Arnaut Oihenart lo hacía de escribir por primera vez versos cultos en euskera, es decir, de ser un poeta a la manera de los clásicos (los petrarquistas en España, Italia y Francia). De este modo se dirige el poeta a las Musas tras el fallecimiento de su esposa Joana : 
"Señoras, os he servido durante mucho tiempo, y he celebrado en nuestro país vuestro nombre que con anterioridad era poco conocido. He sacado de las tinieblas a la luz vuestras costumbres y hábitos, que no se había oído hablar entre vosotros; yo las he hecho salir de lo desconocido, he hecho nuestros y yo las he puesto a disposición de los que escriben poemas en vasco".

Para Oihenart, como para muchos autores a los que había frecuentado, el sometimiento a unas reglas o métrica, el imponerse una disciplina, era la condición indispensable de toda poesía que se tuviera por tal. El "tour de force" que el poeta mantiene con la forma del poema constituye la regla de oro de su valía como poeta. Lo que para el Renacimiento del siglo XVI supuso un refinamiento formal y espiritual, acabaría en el siglo XVIII, con el neoclasicismo, en una suerte de dialecto poético sin vida, una poesía vacua donde no se hablaba de la brisa sino del "blando céfiro" o no se hablaba del sol sino de" Febo".

Sin embargo, la poesía en euskera estaba libre de semejantes excesos. Aun cuando en el resto del Occidente cristiano la poesía era, a un mismo tiempo, heredera de la antigüedad grecorromana y de la tradición judeocristiana -por cuanto que las uvas no sólo eran fruto de donde se extraía el vino, sino que aludían a dos divinidades, Cristo y Baco-, no lo será para una literatura como la vasca, replegada exclusivamente sobre el repertorio de imágenes controladas por una Contrarreforma absolutamente asfixiante. No obstante, como se ha indicado más arriba, aun cristianizado, el imaginario clásico seguía vivo como uno de los elementos constitutivos de la cultura occidental. Realmente, la sola idea de cercenar de la sabia cultural de la lengua cualquier vestigio clásico era un despropósito. Claro que con ello se estaba reduciendo el euskera escrito a pura y simple expresión vehicular de la doctrina postridentina.

A los pocos años de la muerte de Oihenart, el jesuita y poeta Gazteluzar - en opinión de Lafitte, "el poeta más fino del siglo XVII" (Lafitte, 1941: 39)- mostraba su sorpresa por la insistencia de Oihenart en las musas, máxime cuando tenía, como él, a mano la Sagrada Escritura. Con estas palabras conjuraba Gazteluzar la verdadera musa divina frente a las falsas y profanas en su libro Eguia Catolicoac [Verdades Católicas, 1686]:

\section{1. "Urrun adi, Parnasoko}

Musa zahar profanoa;

Eta zu, zato, zeruko

Musa berri dibinoa. 


\section{Jesus-Kristo gure jauna}

Ekhar bezate bihotzek,

Ithurriek ur saindua,

Fruitu bizia haritzek.

3. Adio, Febo, hire etxe,

Hire itsaso guztia,

Ez zarete asko hiltzeko

Ene egarria handia".

(1. Aléjate, vieja Musa profana del Parnaso. Y ven, nueva Musa divina y celeste. 2. Que los corazones lleven a nuestro señor Jesucristo, las fuentes agua santa y los robles fruto vivo. 3. Adios, Febo, tu casa, tu océano entero no se basta para aplacar mi gran sed").

Para Caro Baroja, Oihenart fue un hombre agudo y crítico. Sin embargo, no serán estas cualidades las mejor ponderadas por estudiosos vascos del siglo XX como los sacerdotes Pierre Lafitte o Patxi Altuna. El primero de ellos no trata sin cierto desdén la invocación que el poeta de Maule hace de las Musas. Mientras que para Lafitte, Etcheberri de Ciboure, escritor de manuales de devoción y villancicos edificantes, "no debería morir nunca en el corazón de los vascos, P. Altuna se revuelve contra el juicio crítico - "ofensivo" en sus palabras- que le mereció a Oihenart la obra poética de Etcheberri. Para el jesuita azpeitiarra, el poeta de Ciboure hubiera debido ser proclamado, cuanto menos, "hijo predilecto de Euskal Herria". Claro que este decantamiento espiritual nada tenía que ver con la poesía y sí en cambio con la religión. Nos encontramos ante un episodio tardío de la ya más que centenaria batalla pastoral que venía librando la Iglesia Católica de este país desde la Contrarreforma y que culminó en la identificación de lo vasco con el catolicismo. Koldo Mitxelena fue certero cuando sostuvo que "si un hecho en la historia moderna ha tenido una profunda repercusión en Vasconia, éste es el Concilio de Trento, cuyos efectos llegaron a conformar de modo permanente casi todos los aspectos de la vida del país. Después de él y en su consecuencia va realizándose la identificación, luego familiar, de lo vasco con el catolicismo. Donde las palabras de Caro Baroja representan el espíritu liberal de la Modernidad, el Humanismo y la Ilustración, los juicios de Lafitte y Altuna son herederos del trađicionalismo católico. 


\section{Bibliografía}

ALTUNA, P. : Versificación de Dechepare. Métrica y pronunciación. Bilbo, 1979.

ALTUNA, P. : Linguae Vasconum Primitiae (edizio kritikoa). Bilbo, 1980.

ALTUNA, P. : "Lapurtarrak Oihenartekin hasarre?". Hegats, 7, 1992, 10-16. Iker, $1994,8,477-484$.

ALTUNA, P.: "Etxepareren 450. urteurrenaren hondakinak". Mundaiz, 51, 1996, 925 .

ARKOTXA, A. : "Oihenarten amodiozko poesien azterketa konparatiboa", Iker. 8 , 1994, 401-450.

ARKOTXA, A. : "Etxeparekoaren maitasunezko kopletaz. I". Sancho el Sabio, 6, $1996,211-234$.

HEGATS : Arnaud Oihenarten omenez. 7, 1992, Monografikoa.

HULZINGA, J. : El otoño de la Edad Media, Madrid, Alianza, 1979.

IKER: Oihenarten laugarren mendeurrena. 8, 1994, Monografikoa.

IRASTORZA, T. : "Oihenarten poemagintza". Hegats, 7, 1992, 17-33.

JUARISTI, J. : Literatura vasca, Taurus, Madrid, 1987.

JUARISTI, J. : "De métrica vascorrománica". ASJU, 1990: 2, 381-405.

KORTAZAR, J. : Euskal literaturaren historia txikia, Donostia, Erein, 1997.

LAFON, R. : "Bernard Dechepare; les Prémices de la langue des Basques. Traduction française". BAP, 7: 4, 1951, 485-505-, y 8: 1, 1952, 3-20.

LAFITTE, P.: Le basque et la littérature d'expression basque en Labourd, BasseNavarre et Soule. Bayonne, Le Livre, 1941.

LAPESA, R.: De la Edad Media a nuestros días, Madrid, Gredos, 1967.

MITXELENA, L. : "Arnault Oihenart", BAP, 9: 3, 1953, 445-463.

MICHELENA, L. : Historia de la literatura vasca, Minotauro, Madrid, 1960.

OIHENART, A. : L'Art Poétique Basque (1965), Ed. De P. Lafitte, GH, 1967.

ORPUSTAN, J. B. : "Réalisme et fantasie narrative chez A. Oihenart". Memoriae L. Mitxelena magistri sacrum. Diputación Foral de Gipuzkoa, 1990, 201 216.

ORPUSTAN, J. B. : "Bernart Etxepare ta Arnalde Oihenart: ondoriotasunetik harat". Iker. 8, 1994, 451-465. Hegats, 7, 1992, 59-72.

ORPUSTAN, J. B. : Précis d'histoire littéraire basque. 1545-1950, Izpegi, Baigorri, 1996, 298. or. 